\title{
The need for the application of modern chemical insecticides and environmental consequences of their use: a mini review
}

\author{
Volodymyr V. Oberemok ${ }^{1}$, Kateryna V. Laikova ${ }^{2}$, Aleksei S. Zaitsev ${ }^{1}$, Zenure Z. Temirova ${ }^{1}$, \\ Nikita V. Gal'chinsky ${ }^{1}$, Palmah M. Nyadar ${ }^{1}$, Maksym N. Shumskykh ${ }^{1 *}$, Ilya V. Zubarev ${ }^{3}$ \\ ${ }^{1}$ Department of Biochemistry, Faculty of Biology and Chemistry, Taurida Academy, V.I. Vernadsky Crimean Federal University, \\ Simferopol, Crimea \\ ${ }^{2}$ Department of Biochemistry, Medical Academy, V.I. Vernadsky Crimean Federal University, Simferopol, Crimea \\ ${ }^{3}$ Institute of Natural Sciences, Ural Federal University, Chelyabinsk, Russia
}

Vol. 57, No. 4: 427-432, 2017

DOI: 10.1515/jppr-2017-0044

Received: August 7, 2017

Accepted: October 23, 2017

*Corresponding address:

hinon@list.ru

\begin{abstract}
Currently, the use of insecticides is an acute problem. Due to rapid population growth, the primary task is to increase food production. Beyond abiotic factors (drought, soil salinity, etc.) that reduce crop yields, farmers face problems with insect pests that can decrease crop productivity up to $60 \%$. Also, insects are carriers of severe viral and protozoan human diseases. The need for application of insecticides is not questioned but many of them cause resistance of insect pests to them. This, in turn, leads to the necessity to invent new insecticides that are safe and more effective for long-term use. Preparations based on conservative parts of nucleic acids, particularly contact DNA insecticides, could be used to solve insecticide resistance problem as control agents which are well-tailored to target insect pests. This mini review is devoted to these issues.
\end{abstract}

Key words: chemical insecticides, DNA insecticides, insect pests, insecticide resistance, plant protection

\section{Introduction}

Two hundred years ago, around 1 billion people lived on our planet, but today there are more than 7.5 billion people. Developments in science, medicine and biotechnology are the reasons for such a population explosion. Despite rapid advancements in scientific potential, the standard of living of many people in Asia and Africa is near the poverty level. In developing countries, especially in rural areas, every fifth person is affected by hunger (Atinmo et al. 2009). The deficiency of vitamin $\mathrm{A}$, iron and iodine is also a common issue for these countries (Hunt 2005; Atinmo et al. 2009; Mirmiran et al. 2012). About 300 million people fight for survival every day. Thousands of them, especially children, lose this battle (Atinmo et al. 2009; Gulati 2010). In many respects, the current situation is explained by a great loss of crops caused by abiotic (irradiation, water, temperature and nutrients) and biotic (weeds, animal pests and pathogens) factors. Overall, weeds are responsible for the greatest losses (34\%), with animal pests and pathogens being less important (losses of 18 and 16\%, respectively) (Oerke 2006). Among pests, insects cause the greatest harm to crops. More than 10,000 species of insect pests can attack plants (Dhaliwal et al. 2007). They cause drying up of trees, and full or partial damage of agricultural plants and herbs, thereby reducing their productivity. They also damage the stored products, spoil the appearance of ornamental plants, and transfer viral and protozoan diseases, etc. For example, the area of the Colorado potato beetle [Leptinotarsa decemlineata (Say)] has already reached 16 million $\mathrm{km}^{2}$ in North America, Europe and Asia and continues growing (Weber 2003). The 2016 gypsy moth [Lymantria dispar (Linnaeus)] population boom caused over 349,000 acres of damage 
statewide in Massachusetts (USA) (Charles 2017). In 2007 on a global market 11.2 billion dollars were spent on the purchase of insecticides. This comprises nearly $28 \%$ of all world expenses on pesticides (Grube et al. 2011).

\section{The need for the application of insecticides and reasons for the creation of new preparations}

Despite the fact that every year new insecticides are developed for plant protection, the cost of losses from insect pests stays almost at the same level, about 30\% of pre-crop part and 10\% of post-crop part (Sanchis 2011). Taking into consideration the rapid population growth, the annual reduction of cultivated areas and substantial losses from insect pests, most experts consider that there is no serious alternative to insecticides (Furlan and Kreutzweiser 2015) because they help to preserve 20\% of all crops (Oerke and Dehne 2004). Also, it is impossible to overestimate the role of insecticides in the prevention of viral and protozoan diseases (Aktar et al. 2009). For example, diseases transmitted by mosquitoes, including malaria, yellow fever, Japanese encephalitis, filariasis and others are spread in more than 100 countries. Worldwide, each year more than 700 million people are infected with the participation of insects. Only with the help of insecticides it is possible to reduce the significant occurrence of these insect-borne diseases (Ghosh et al. 2012).

It should be noted that in nature the number of insects is regulated by parasites without human intervention. Insect population outbreaks eventually are replaced by a population decline (Lotka-Volterra predator-prey model) (Weisberg and Reisman 2008). It is a constant process which is uncontrollable by human. But in an agrobiocenosis, the number of insect pests should be permanently kept under control in order to save a particular crop. Furthermore, it is necessary to consider r-strategy of insects survival in which a large number of descendants are formed (Odum 1986; Karunaratne 1998). Based on the Lotka-Volterra model, during the decline of the pest population under the action of a parasite, the population of the parasite also decreases with some delay (Odum 1986; Weisberg and Reisman 2008). Thus, in the insect population, during the phase of decline, the majority of individuals have genotypes that are adapted for parasites which have genotypes prevailing at the moment. Under these circumstances, the insect population will start to grow until the genotypes of the parasite population, capable of suppressing the insect pest population significantly, appear again. The same line of reasoning can be applied to a "chemical insecticide-insect pest" system. The only exception is an insecticide can't change by itself. Proceding from this situation, in agriculture and forestry it is necessary to apply insecticides constantly, changing them every few years to avoid the emergence of insecticide resistance to chemical and biological preparations (Daly et al. 1998; Read et al. 2009; Gourley et al. 2011). Taking into consideration such genetic mechanisms as mutations, random assortment of homologous chromosomes during meiosis, crossingover, amplification of genes of cytochrome P450 monooxygenases, etc., it is impossible to imagine how an insect pest can be deprived of the opportunity to generate insecticide resistance. For example, after World War II the operational validity of chemical insecticides for malaria control in regions with their wide use averaged only about 5 years (Koella et al. 2009).

In 1979 the United Nations Environment Programme (UNEP) declared that globally pesticide resistance is an environmental problem (Sanchis 2011). The general mechanism underlying insecticide resistance is the natural selection that leads to an increase in frequency of resistance alleles, formed as a result of random mutations, in insect pest population (Fig. 1). The emergence of resistance to insecticides is an example of Darwin's microevolution. Most experts agree that if the pressure of natural selection is not reduced, resistance to the used insecticide always appears. Thus, the only alternative to modern insecticides is in creation and use of new preparations that are selective and less dangerous for the environment (Van Steenwyk and Zalom 2005; Koella et al. 2009; Read et al. 2009; Gourley et al. 2011). First of all, it concerns chemical insecticides (carbamates, organophosphates, pyrethroids, neonicotinoids, etc.) because biological preparations (bacteria, viruses) have minimum negative impact on the environment, but unfortunately, they are less affordable and less effective than chemical preparations.

There are also cases when resistance to insecticides does not develop, e.g. the absence of resistance to DDT in the tsetse fly (Hemingway and Ranson 2000). This is explained by the fact that this insect leaves few offspring, thereby not allowing the emergence of a "successful mutation". Actually, resistance to the insecticide does develop, but very slowly. The emergence of resistance to insecticides is a normal evolutionary phenomenon leading to adaptation of an insect pest to environmental conditions. In this regard, it is impossible to talk about an insecticide which can completely solve the problem of controlling any target insect pest, perhaps with a number of exceptions.

It is possible to slow down the emergence of insecticide resistance through the creation of preparations blocking the functioning of cell structures which change very slowly during microevolution. For example, preparations based on conservative parts of nucleic acids can be used for this purpose. The effect of such preparations is based on mechanisms of 


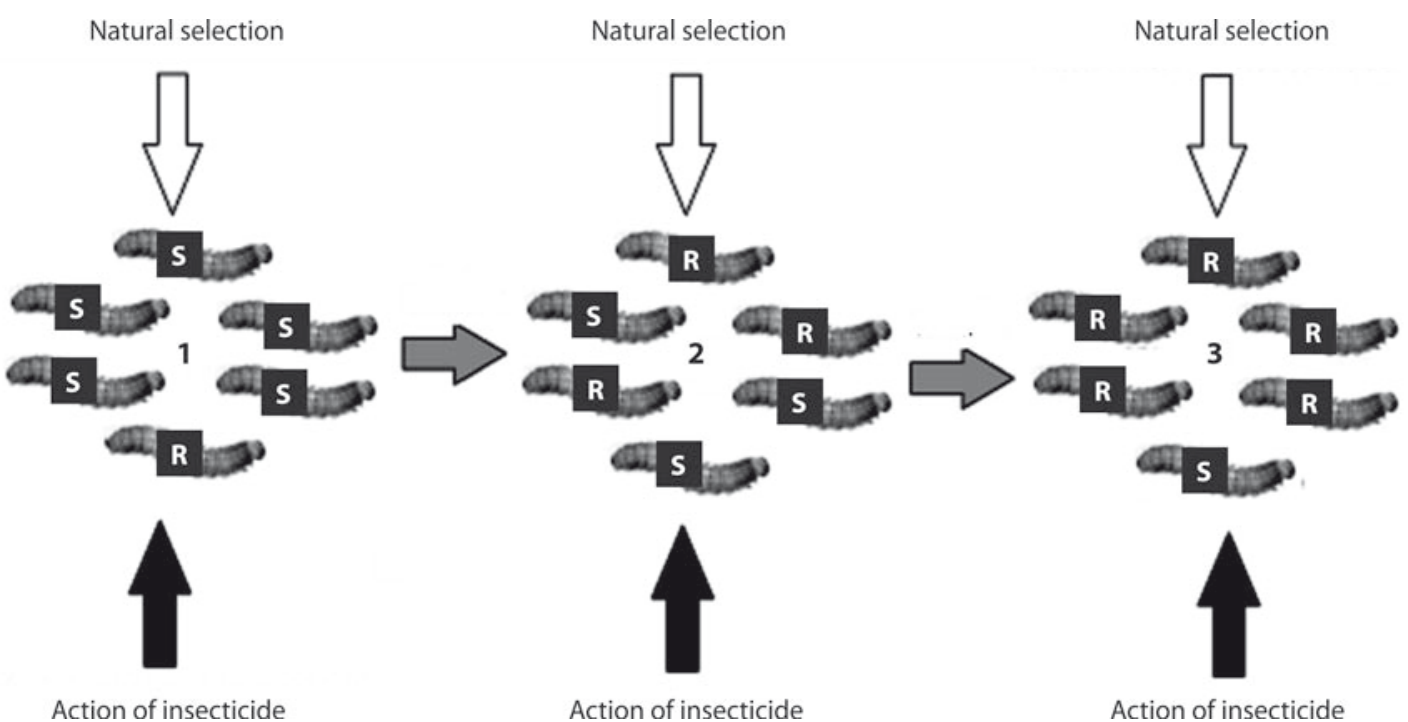

Fig. 1. Scheme of the emergence of resistance to insecticides: 1, 2, 3- the composition of the population of an insect pest in generations which varies with time under the influence of the applied insecticide and natural selection; $\mathrm{S}$ - insecticide-sensitive individuals of the insect pest; $\mathrm{R}$ - insecticide-resistant individuals of the insect pest

posttranscriptional inactivation of genes (antisense oligonucleotides, RNA-DNA hybrids, RNAi approach) (Lin and Ying 2001; Dias and Stein 2002; Zotti and Smagghe 2015). The functionally important genes and their conservative sites for which the speed of mutations is slow can serve as targets for these preparations. Nucleic acids will not be accumulated in the environment, their manufacture will become more and more affordable, and the definite combination of nucleotides in a sequence will be effective only against a certain insect pest. Therefore, in the foreseeable future, the arsenal of existing insecticides can be supplemented with a new class of preparations based on nucleic acids, e.g. contact DNA insecticides (Simchuk et al. 2012; Oberemok et al. 2015, 2016, 2017). In particular, in our research antisense conservative DNA oligonucleotide, oligoRING (5'-CGA CGT GGT GGC ACG GCG-3') from RING (really interesting new gene) domain of IAP-3 (inhibitor of apoptosis) gene of $L$. dispar multicapsid nuclear polyhedrosis virus (LdMNPV) which is complementary to host IAP- $Z$ gene, can elevate the mortality of LdMNPV-free and LdMNPV-infected gypsy moth $(L$. dispar) larvae. The results of elevated insect mortality, down-regulation of target IAP genes, strong apoptotic DNA fragmentation, decreased biomass accumulation, and a decreased number of developed female imagos suggested that oligoRING induces apoptotic processes in both LdMNPV-free and LdMNPV-infected insect cells but they were more pronounced in the latter. These data open possibilities for new promising routes of insect pest control using antisense DNA oligonucleotides from conservative parts of functionally important genes of apoptosisantiapoptosis system.

\section{Environmental impact of insecticides}

Chemical and bioactive properties of insecticides, released into the environment, make their inclusion into bioaccumulation and biotransformation processes inevitable. During the process of bioaccumulation, the multiple increase of insecticide concentration (biomagnification) occurs as it passes through a food chain (Essumang et al. 2009; Hu et al. 2010; Ghosh et al. 2012). Thus, with each subsequent link of a food chain, the amount of insecticide can be increased by 10-20 times (Essumang et al. 2009). For this reason, the insecticides which are not found in the abiotic environment can be present in the tissues of living organisms at very significant and biologically dangerous concentrations. It is assumed that during treatment of crops, only about $0.1 \%$ of the insecticides reach insect pests (Carriger et al. 2006), whereas most applications of the insecticides miss the target and $99.9 \%$ go into the soil, water reservoirs, the atmosphere and from there into plants, animals and human organisms. The chemicals, as a major part of the world market of insecticides, enter food chains involving not only the target insect pests but also other participants of the ecosystem. For example, DDT, a popular insecticide in the past, is capable of accumulating in adipose tissue of animals and human. Despite its low solubility in water, its bioconcentration occurs in aquatic organisms, and the content of DDT in some hydrobionts reaches 223.9 mikrogramms per $1 \mathrm{~kg}$ of wet biomass (Malakhova 2014). Along with the bioaccumulation of insecticides, the processes of their transformation occur. Any applied insecticide sooner or later undergoes decomposition either in the organisms of 
plants, animals, microorganisms, or under the influence of physical and chemical factors of the environment. Futhermore, the processes of degradation can be accompanied by the detoxification of insecticides (Sogorb and Vilanova 2002), a loss of toxic properties by the initial substance, as well as by toxification, a creation of more toxic substances. For example, the malathion molecule, which can miss the target insect pest, under the influence of sunlight is oxidized into more toxic malaoxon. Malaoxon, in turn, is more dangerous not only for insects but also for warm-blooded animals (Aker et al. 2008).

Such often-used insecticides like organophosphates are highly toxic for human health. Organophosphorous insecticides are mutagens and teratogens. A large number of modern diseases of the nervous and immune systems of mammals can be caused by their effect, e.g. Parkinson's disease, Alzheimer's disease, multiple sclerosis, etc. This emphasizes the need for more careful investigation of the toxicological profiles of organophosphates and other insecticides (Ragnarsdottir 2010). There are also cases of poisoning by contamination with insecticide products, casual professional intoxications, as well as the use of insecticides for suicide purposes. It was calculated that in Asia around 200,000 people die each year from self-poisoning by organophosphorous insecticides (Eddleston et al. 2008). In rural areas of China, $60 \%$ of all suicides are committed by self-poisoning with pesticides (Phillips et al. 2002).

It should be noted that modern and frequently used neonicotinoid and pyrethroid pesticides are harmful for the environment as well. Neonicotinoid insecticides are a threat to vertebrates due to their high toxicity, environmental persistence, water solubility, and potential for surface- and groundwater contamination (Zeng et al. 2013). Pyrethroids are ion channel toxins that interfere with the function of the nervous system. The toxic effects of pyrethroids result from this neuronal excitation and include a wide spectrum of signs and symptoms from paraesthesia and increased salivation, to seizures and potentially death (Bradberry et al. 2005). Though claimed to be selectively toxic to insects, synthetic pyrethroids are extremely toxic to aquatic organisms, including fish in concentrations similar to those used for controlling mosquitoes, black flies and tsetse fly larvae, which are the actual targets of pyrethroids. Many pyrethroids have been linked to the disruption of the endocrine system, reproduction and sexual development, interference with the immune system and the induction of breast cancer. The widespread use of pyrethroids is a major problem as they pollute agricultural lands and water resources and affect non-target organisms and humans (Thatheyus et al. 2013).

It is necessary to take into account that each insect pest species, which is subject to control, lives together with hundreds of non-target species which are essential for ecosystem balance. This is especially true when it concerns natural enemies of the target insect pests that can reach dozens of species in specific places. For example, in certain areas of Mexico, there are 18 insect species which are parasites of the Colorado potato beetle (L. decemlineata) (Cappaert et al. 1991). Their elimination is undesirable. How one can efficiently and protractedly control populations of the target insect pests with pinpoint accuracy, without affecting non-target organisms? It is necessary to apply advanced knowledge of biology and chemistry in order to create such insecticides. One thing is certain, there are still no insecticides on the global market with both safe and efficient properties. From the viewpoint of safety and selectivity the development of the above mentioned DNA insecticides is also promising. DNA insecticides designed for gypsy moth (L. dispar) larvae can be selective, and thus non-harmful for non-target insects, such as black cutworm [(Agrotis ipsilon (Hufnagel)] and tobacco hornworm [(Manduca sexta (Linnaeus)] (Oberemok and Skorokhod 2014). By evaluating alkaline phosphatase activity, glucose concentration and biomass accumulation, we also determined that DNA insecticides do not have a long-term negative effect on plants such as wheat (Triticum aestivum L.) (Oberemok et al. 2013), English oak (Quercus robur L.) and apple tree (Malus domestica Mill.) (Zaitsev et al. 2015). This paves the way to the creation of selective DNA insecticides that are well-tailored to target insect pests.

It is important to note, that DNA insecticides can solve the problem of resistance to insecticides. If we use short single-stranded fragments of very conservative parts of host insect antiapoptosis genes, the resistance to insecticides will grow more slowly. This is due to the fact that potential mutations, changing target apoptosis genes, occur at a very slow rate in conservative parts. In this way, if we cannot stop genetic processes that lead to resistance of insecticides, we could slow down the emergence of resistance to insecticides by using DNA insecticides based on very conservative regions of functionally important genes such as the genes of antiapoptosis. Developments in this area can lead to safe and cheap agriculture supported by DNA insecticides (Oberemok et al. 2016).

\section{Conclusions}

Due to undernourishment, food insecurity and the emergence of resistance to insecticides, the need for the application and creation of new chemical insecticides is unquestionable. Unlike developed countries, it is extremely important for developing countries to use insecticides, since refusal to use them threatens a rapid onset of hunger and increases in frequency of insectborne diseases, e.g. malaria. The creation and use of new 
chemicals must be pragmatic. In other words, all actions related to insecticides have to be based first of all on scientific arguments instead of commercial reasons (Aktar et al. 2009). Contact DNA insecticides based on conservative antisense fragments of genes of an apoptosisantiapoptosis system, as next-generation preparations of a post-genomic era, could be used to solve the insecticide resistance problem since they are well-tailored to target insect pests.

\section{Acknowledgements}

We are very much indebted to all anonymous reviewers and our colleagues from «Lab on DNA technologies, PCR analysis and creation of DNA insecticides» (V.I. Vernadsky Crimean Federal University, Taurida Academy, Faculty of Biology and Chemistry, Department of Biochemistry) for valuable comments on our manuscript. Volodymyr V. Oberemok was supported by the Project of Development Program of V.I. Vernadsky Crimean Federal University network «Academic mobility of young scientists of Russia - AMMUR» at FSBSI «Center of experimental embryology and reproductive biotechnologies» and RFBR Grant No. 15-34-50986.

\section{References}

Aker W.G., Hu X., Wang P., Hwang H.M. 2008. Comparing the relative toxicity of malathion and malaoxon in blue catfish Ictalurus furcatus. Environmental Toxicology 23 (4): 548-554. DOI: $10.1002 /$ tox.20371

Aktar W., Sengupta D., Chowdhury A. 2009. Impact of pesticides use in agriculture: their benefits and hazards. Interdisciplinary Toxicology 2 (1): 1-12. DOI: 10.2478/v10102$-009-0001-7$

Atinmo T., Mirmiran P., Oyewole O.E., Belahsen R., Serra-Majem L. 2009. Breaking the poverty/malnutrition cycle in Africa and the Middle East. Nutrition Reviews 67 (1): S40-6. DOI: 10.1111/j.1753-4887.2009.00158.x

Bradberry S.M., Cage S.A., Proudfoot A.T., Vale J.A. 2005. Poisoning due to pyrethroids. Toxicol Review 24 (2): 93-106.

Cappaert D.L., Drummond F.A., Logan P.A. 1991. Incidence of natural enemies of the Colorado potato beetle, Leptinotarsa decemlineata (Coleoptera: Chrysomelidae) on a native host in Mexico. Entomophaga 36 (3): 369-378.

Carriger J.F., Rand G.M., Gardinali P.R., Perry W.B., Tompkins M.S., Fernandez A.M. 2006 Pesticides of potential ecological concern in sediment from South Florida canals: an ecological risk prioritization for aquatic arthropods. Soil and Sediment Contamination 15: 21-45.

Charles D.B. 2017. Gypsy Moth: What to Expect in 2017. Massachusetts Urban \& Community Forestry Program "The Citizen Forester" 199: 1. Available on: http://www.mass.gov/ eea/docs/dcr/stewardship/forestry/urban/citizen-forester/ cf2017feb-.pdf [Accessed: June 30, 2017]

Daly H., Doyen J.T., Purcell A.H. 1998. Introduction to Insect Biology and Diversity. University Press, Oxford, New York, USA, 674 pp.

Dhaliwal G.S., Dhawan A.K., Singh R. 2007. Biodiversity and ecological agriculture: Issues and perspectives. Indian Journal of Ecology 34: 100-109.
Dias N., Stein C.A. 2002. Antisense oligonucleotides: basic concepts and mechanisms. Molecular Cancer Therapeutics 1 (5): 347-355.

Eddleston M., Buckley N.A., Eyer P., Dawson A.H. 2008. Management of acute organophosphorus pesticide poisoning. Lancet 371 (9612): 597-607. DOI: 10.1016/S0140-6736 $-(07) 61202-1$

Essumang D.K., Togoh G.K., Chokky L. 2009. Pesticide residues in water and fish (Lagoon tilapia) samples from lagoons in Ghana. Bulletin of the Chemical Society of Ethiopia 23 (1): 19-27. DOI: http://dx.doi.org/10.4314/bcse.v23i1.21294

Furlan L., Kreutzweiser D. 2015. Alternatives to neonicotinoid insecticides for pest control: case studies in agriculture and forestry. Environmental Science and Pollution Research 22: 135-147. DOI: 10.1007/s11356-014-3628-7

Ghosh A., Chowdhury N., Chandra G. 2012. Plant extracts as potential mosquito larvicides. Indian Journal of Medical Research 135 (5): 581-598.

Gourley S.A., Liu R., Wu J. 2011. Slowing the evolution of insecticide resistance in mosquitoes: a mathematical model. The Royal Society A 467: 2127-2148. DOI: http://dx.doi. org/10.1098/rspa.2010.0413

Grube A., Donaldson D., Kiely T., Wu L. 2011. Pesticides Industry Sales and Usage: 2006 and 2007 Market Estimates. U.S. Environmental Protection Agency, Washington, DC.

Gulati J.K. 2010. Child malnutrition: trends and issues. Anthropologist 12 (2): 131-140.

Hemingway J., Ranson H. 2000. Insecticide resistance in insect vectors of human disease. Annual Review of Entomology 45: 371-391. DOI: 10.1146/annurev.ento.45.1.371

$\mathrm{Hu}$ G. 2010. Concentrations and accumulation features of organochlorine pesticides in the Baiyangdian lake freshwater food web of North China/G. Hu. и др. //. Archives of Environmental Contamination and Toxicology 58 C: 700-710.

Hunt J. 2005. The potential impact of reducing global malnutrition on poverty reduction and economic development. Asia Pacific Journal of Clinical Nutrition 14: 10-38.

Karunaratne S.H.P.P. 1998. Insecticide resistance in insects: A review. Ceylon Journal of Science 25: 72-99.

Koella J.C., Lynch P.A., Thomas M.B., Read A.F. 2009. Towards evolution proof malaria control with insecticides. Evolutionary Applications 2 (4): 469-480. DOI: 10.1111/j.1752$-4571.2009 .00072 . x$

Lin S.-L., Ying S.-Y. 2001. D-RNAi as a novel defense system against cancers and viral infections. Current Cancer Drug Targets 1 (3): 241-247.

Malakhova L., Giragosov V., Khanaychenko A., Malakhova T., Egorov V., Smirnov V. 2014. Partitioning and level of organochlorine compounds in the tissues of the Black Sea Turbot at the South-Western Shelf of Crimea. Turkish Journal of Fisheries and Aquatic Sciences 14: 993-1000. DOI: 10.4194/1303-2712-v14_4_19

Mirmiran P., Golzarand M., Serra-Majem L., Azizi F. 2012. Iron, iodine and vitamin A in the middle East; a systematic review of deficiency and food fortification. Iranian Journal of Public Health 41 (8): 8-19.

Oberemok V.V., Nyadar P.M., Zaytsev O.S., Levchenko N.N., Shiyntum H.N., Omelchenko O.V. 2013. Pioneer evaluation of the possible side effects of the DNA insecticides on wheat (Triticum aestivum L.). International Journal of Biochemistry and Biophysics 1 (3): 57-63. DOI: 10.13189/ ijbb.2013.010302

Oberemok V.V., Skorokhod O.A. 2014. Single-stranded DNA fragments of insect-specific nuclear polyhedrosis virus act as selective DNA insecticides for gypsy moth control. Pesticide Biochemistry Physiology 113: 1-7.

Oberemok V.V., Laikova K.V., Gninenko Y.I., Zaitsev A.S., Nyadar P.M., Adeyemi T.A. 2015. A short history of insecticides. Journal of Plant Protection Research 55 (3): 221-226.

Oberemok V.V., Laikova K.V., Zaitsev A.S., Gushchin V.A., Skorokhod O.A. 2016. The RING for gypsy moth control: topical application of fragment of its nuclear poly- 
hedrosis virus antiapoptosis gene as insecticide. Pesticide Biochemistry and Physiology 131: 32-39. DOI: 10.1016/j. pestbp.2016.01.006

Oberemok V.V., Laikova K.V., Zaitsev A.S., Nyadar P.M., Gninenko Yu.I., Gushchin V.A., Makarov V.V., Agranovsky A.A. 2017. Topical treatment of LdMNPV-infected gypsy moth larvae with 18 nucleotides long antisense fragment from LdMNPV IAP-3 gene triggers higher level of apoptosis in the infected cells and mortality of the pest. Journal of Plant Protection Research 57 (1): 18-24.

Odum Yu. 1986. Ekologiya [Ecology]. Moscow, 325 pp.

Oerke E.C. 2006. Crop losses to pests. Centenary review. Journal of Agricultural Science 144: 31-43. DOI: 10.1017/ S0021859605005708

Oerke E.C., Dehne H.W. 2004. Safeguarding production-losses in major crops and the role of crop protection. Crop Protection 23: 275-285. DOI: 10.1016/j.cropro.2003.10.001

Phillips A.T., Wellman H.M., Spelke E.S. 2002. Infants'ability to connect gaze and emotional expression to intentional action. Cognition 85 (1): 53-78.

Ragnarsdottir K.V. 2010. Environmental fate and toxicology of organophosphate pesticides. Journal of the Geological Society $157: 859-876$.

Read A.F., Lynch P.A., Thomas M.B. 2009. How to make evolution-proof insecticides for malaria control. PLoS Biology 7 (4): 1-10. DOI: 10.1371/journal.pbio. 1000058

Sanchis V. 2011. From microbial sprays to insect-resistant transgenic plants: history of the biopesticide Bacillus thuringiensis. A review. Agronomy for Sustainable Development 31 (1): 217-231. DOI: 10.1051/agro/2010027

Simchuk A.P., Oberemok V.V., Ivashov A.V. 2012. Genetics of interactions among moths, their host plants and enemies in
Crimean oak, forest, and its perspective for their control. p. 187-205. In: "Moths: Types, Ecological Significance and Control" (L. Cauterruccio, ed.). Nova Science Publishers, New York, 286 pp.

Sogorb M.A., Vilanova E. 2002. Enzymes involved in the detoxification of organophosphorus, carbamate and pyrethroid insecticides through hydrolysis. Toxicology Letters 128 (1-3): 215-228. DOI: https://doi.org/10.1016/S0378-4274 $-(01) 00543-4$

Thatheyus A.J., Deborah Gnana Selvam A. 2013. Synthetic Pyrethroids: Toxicity and Biodegradation. Applied Ecology and Environmental Sciences 1 (3): 33-36. DOI: 10.12691/ aees-1-3-2.

Van Steenwyk R.A., Zalom F.G. 2005. Food quality protection act launches search for pest management alternatives. California Agriculture 59 (1): 7-10.

Weber D. 2003. Colorado beetle: Pest on the move. Pesticide Outlook 14 (6): 256-259. DOI: 10.1039/B314847P

Weisberg M., Reisman K. 2008. The robust Volterra principle. Philippine Science 75: 106-131.

Zaitsev A.S., Omel'chenko O.V., Nyadar P.M., Oberemok V.V. 2015. Influence of DNA oligonucleotides used as insecticides on biochemical parameters of Quercus robur and Malus domestica. Bulletin of the Transilvania University of Brasov 8: 37-46.

Zeng G., Chen M., Zeng Z. 2013. Risks of neonicotinoid pesticides. Science 340 (6139): 1403. DOI: 10.1126/science. .340.6139.1403-a

Zotti M.J., Smagghe G. 2015. RNAi technology for insect management and protection of beneficial insects from diseases: lessons, challenges and risk assessments. Neotropical Entomology 44 (3): 197-213. 